\title{
TQM Implementation in an Indonesian Remanufacturing Company with a Long-Term Relationship with Customer Satisfaction and Business Performance
}

\author{
Bayu Cahyono ${ }^{1,2}$ Sumarsono $^{2}$ Dena Hendriana ${ }^{2, *}$ Gembong Baskoro ${ }^{2}$ Henry
}

Nasution $^{2}$

\author{
${ }^{1}$ United Tractors. Tbk., Jakarta - Indonesia \\ ${ }^{2}$ Master of Mechanical Engineering, Swiss German University, Tangerang - Indonesia \\ "Corresponding author. Email: dena.hendriana@sgu.ac.id
}

\begin{abstract}
Total Quality Management (TQM) implementation highlights two critical components of daily management and policy management that must be guaranteed to assure customer satisfaction and corporate performance. The researchers concentrated on the success of TQM adoption through internal management diagnostic and customer satisfaction surveys to address this issue. The primary goal of this study is to examine the relationship between TQM implementation effectiveness and its effects on customer satisfaction and business performance utilizing the Quality Function Deployment (QFD) approach. TQM implementation was found to have a beneficial influence on customer satisfaction and business performance, with a correlation seen in daily management and policy management effectiveness utilizing the QFD technique. TQM implementation focuses on parts of day-today management and policy deployment. An internal diagnosis is required by management as a feedback loop for evaluating to create a sustainable TQM implementation. The QFD method can ensure the linkage between day-to-day management and policy management, which is carried out according to the results of the customer satisfaction survey and business performance to ensure the effectiveness of the necessary improvements.
\end{abstract}

Keywords: Total Quality Management, Quality Function Deployment, Customer Satisfaction, Business Performance.

\section{INTRODUCTION}

Most companies are trying to satisfy their customer's needs and expectations through: improvement in product quality, increased customer satisfaction, and continues improvement towards world class organizations [1]. Total Quality Management (TQM) represents "Policy Development" which means changes and improvement in the conventional ways drastically, as well as "Daily management" which means daily small improvements. The implementation of TQM is emphasized on two important aspects in Daily Management (DM) and Policy Management (PM) which periodically need to be diagnosed as feedback on continuous improvement of TQM implementation is shown in Figure 1. Sustainable TQM implementation must have an impact on customer satisfaction and company's business performance.

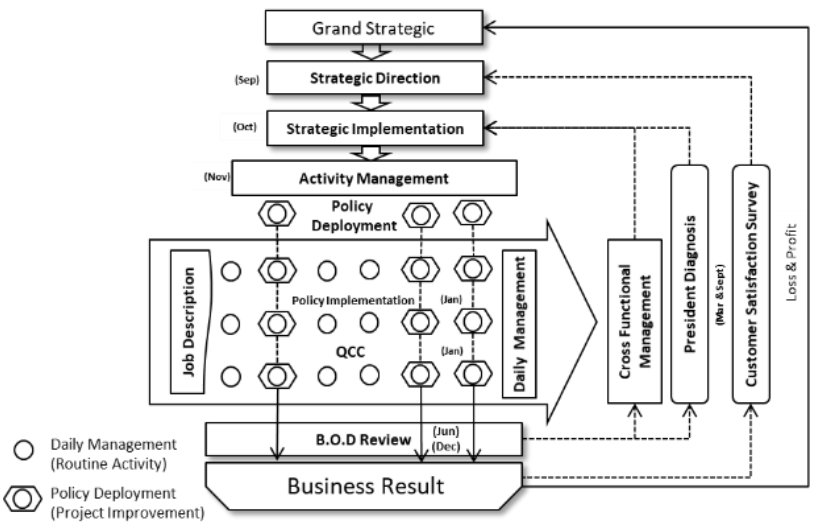

Figure 1 Total Quality Management outline.

Total Quality Management focuses on product and process. It focuses on the company's business, which starts from determining the company's grand strategy and implementation strategy to carrying out the activity management needed to achieve its business performance and customer satisfaction [2-3]. This research ensures the necessary framework so that TQM can be 
appropriately implemented and looks for the approaches required to ensure that TQM implementation will impact customer satisfaction and the company's business performance.

This research aims to propose a framework for implementing sustainable TQM and ensure that Daily Management and Policy Management activities are in line with efforts to achieve customer satisfaction and the company's business performance. A particular approach is needed to ensure the successful implementation of TQM to impact customer satisfaction and company business performance.

\section{LITERATURE REVIEW}

\subsection{Company Management System}

A company Management System is a management system that involves all employees to manage and improve the quality of business processes through an alignment process between strategy and execution, continuous improvement and innovation to achieve customer satisfaction and increase competitiveness.

Company management systems have functioned as: (1) Guidelines for running the management system, (2) Aligning company goals and strategies to the activity level of each individual, (3) Encouraging improvement and innovation activities throughout the company starting from individual level up to company level [4].

As a system, the company management system is integrated with the company value system, which is a system of values and norms that underlie the company, methods, procedures, policies, and work behaviour of all company employees.

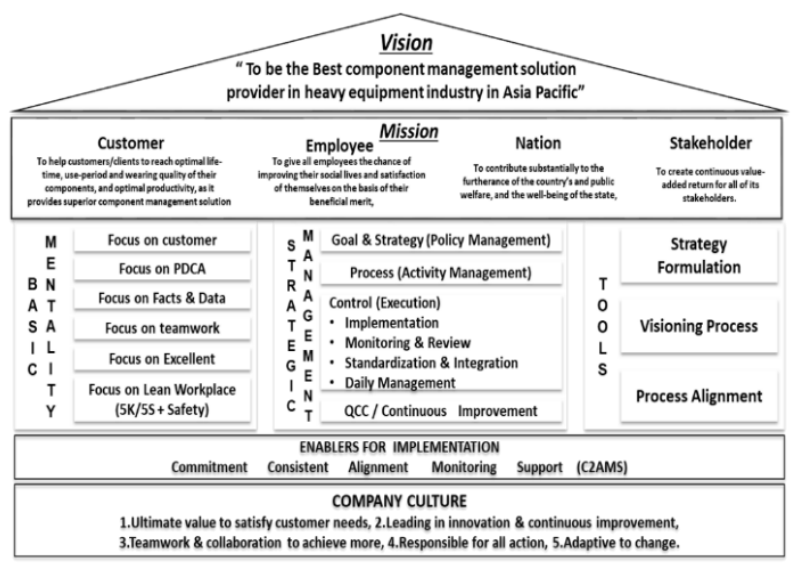

Figure 2 House of Total Quality Management [4]

The Company Management System represented as the House of Total Quality Management is shown in Figure 2 consists of four pillars [4]:

\section{A. Basic Mentality}

The mental attitude that underlies the way of thinking and acting following company values. Basic Mentality includes: (1) Focus on Customer, (2) Focus on PDCA, (3) Focus on Fact and Data, (4) Focus on Teamwork, (5) Focus on Excellence, and (6) Focus on Lean Workplace [4].

\section{B. Strategic Management}

Strategic management ensures that the process of strategy formulation (Policy Management) through to its translation (Policy Deployment) and execution (Activity Management) is carried out correctly. Improvement and innovation activities are inseparable parts of Policy Management and Activity Management. Strategic Management is carried out by rotating the PDCA cycle at all organizational levels, both at the strategic and operational levels.

The PDCA cycle in Strategic Management is divided into the following 5 phases. There are eight steps within each of these phases, as shown in the following chart shown in Figure 3 [4].

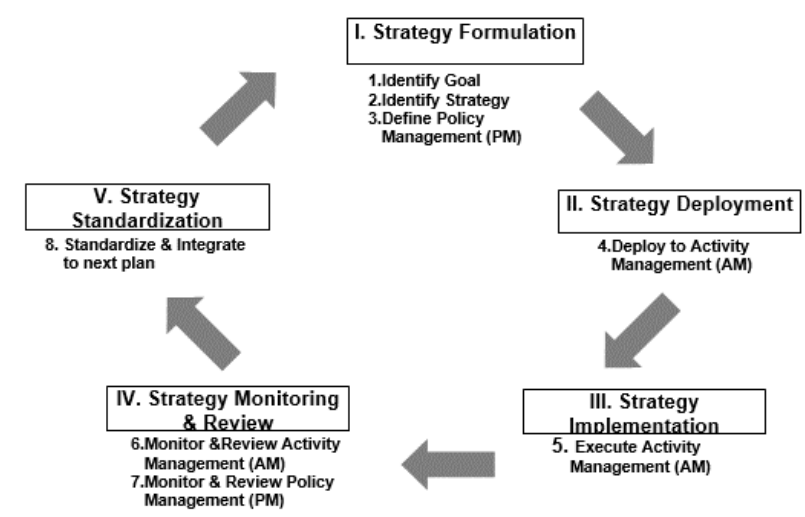

Figure 35 phases of Strategic Management

\section{Tools}

In carrying out each phase of strategic management, several tools are needed so that each stage can produce output as expected. What is expected is not only good output but also correct in the process.

\section{Enabler for Implementation}

In facing the challenges and obstacles of strategy implementation, companies need enablers. This aspect can help the company provide understanding and acceptance of the strategy by the organization, allocate resources that support the strategy, monitor implementation and continue to learn to improve strategic management. 


\subsection{Previous Studies}

Total quality management (TQM) is an integrated management philosophy aimed at continuously improving products and processes to achieve better customer satisfaction [3].

The past TQM literature reported mixed and ambiguous relationships between TQM practices and an organization's performance. This study aims to develop and propose the conceptual framework and research model of TQM implementation concerning organization performance, consisting of Satisfaction Result and Business Result is shown in Figure 4.

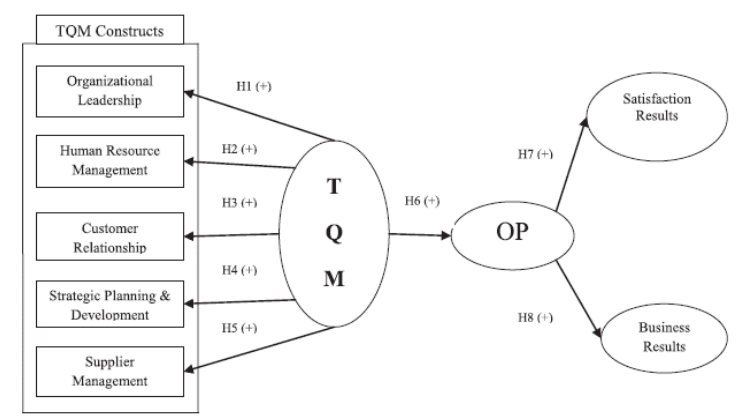

Figure 4 Conceptual research framework linking the TQM and Organization Performance [3]

\section{RESEARCH METHODES}

\subsection{Research Frameworks}

The detail framework of the research is shown in Figure 5.

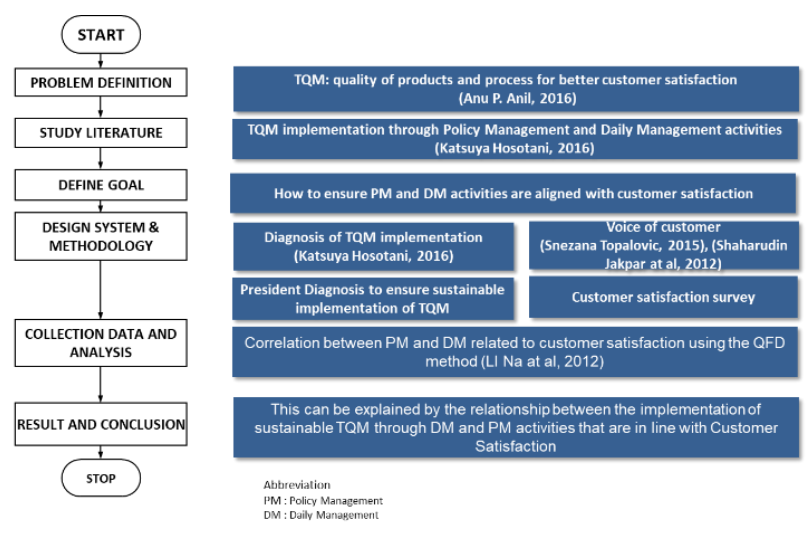

Figure 5 Research framework

\subsection{Structured Interview Diagnosis (President Diagnosis)}

Top management executives and managers should identify the weak points in the activity processes by comparing them to the activity targets and then comprehensively evaluating the promotion of TQM activities. Both the diagnosed party and the diagnosing party should bilaterally determine the measures needed. Therefore, self-improvement is required from the diagnosing party as well as from the diagnosed party.

With the President's decisive leadership and all the staff's dedicated efforts and enthusiasm, these activities will lead to a smoother TQM promotion PDCA cycle and enable promotion targets in a shorter period.

Internal diagnosis check sheet:

\section{A. Policy Management Deployment}

1. Are Strategic Direction deploy to Strategic Implementation in each Division?

2. Are Strategic Implementation in each division deploy to Activity Management in each Dept./Plant?

3. Are additional B.O.D instructions reflected in the Strategic Implementation (Division) and Activity Management (Department/Plant) in the current year?

4. Do Division Head catch requirements of business situation change?

5. Due to business situation change, do Division Head add or revise their Strategic Implementation?

6. Are the problem/constraint in the previous year is the basis in determining the current Strategic Implementation and Division Target?

7. Do each Division Head understand each target in their Strategic Implementation?

8. Are the descendants of the Strategic Implementation Division made Project Management Improvement? (documented \& standardized)

9. Are the problem/constraint in the previous year is the basis in determining the current Activity Management and Dept. Target?

10. Are the target of the Activity Management (Detail Activity Plan) is measured?

11. Are Strategic Implementation managed well \& reviewed every month?

12. Are un-achieved result in Strategic Implementation followed by PICA?

13. Do Mgr follow up strategic Implementation every month?

14. Are problems cleared by monthly activity?

15. Do Division Head take action for concretely?

\section{B. Daily Management}


1. Are there clear job description in each function applied?

2. Are there relation between job description \& control item in Daily Management?

3. Are there clear target (number) in every control item?

4. Are there clear target for every month?

5. Are there any issued PICA for un-achieved result?

6. Are PICA followed up?

\section{Improvement Confirmation Review (Every Semester)}

7. Do they recognize their problems in their section?

8. Do they take action to solve the problem?

9. Do they make preventive action?

D. Tools

10. Do Division Head understand about BOD Comment?

11. Do they follow-up BOD comment?

12. Are there clear action plan for BOD Comment follow-up?

13. Are there any progress of BOD Comment followup?

Internal diagnostics carried out at a leading heavy equipment remanufacturing company in Indonesia related to the initial application of TQM showed in Figure 6.

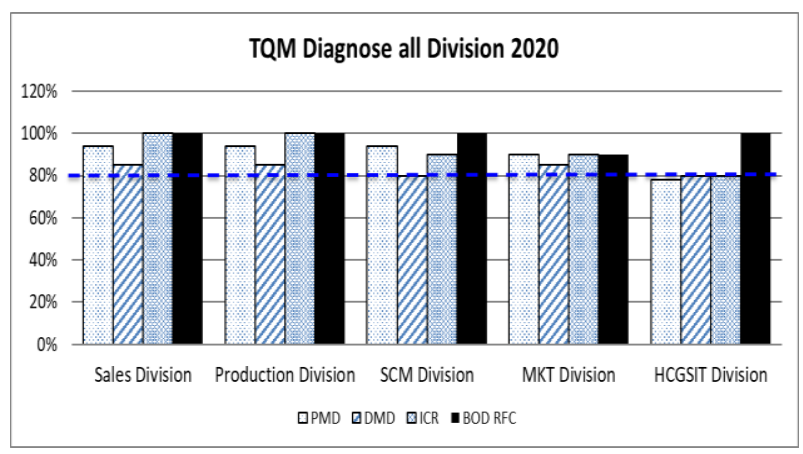

Figure 6 Result of internal diagnosis - All Division

The initial implementation of TQM showed results: show values above $80 \%$, offers a reasonably good value for the initial implementation of TQM.

\subsection{Customer Survey}

A survey was conducted to see the percentage of service quality and product quality based on customer satisfaction in using company repair services [5].
Measurements are aimed at customers who transact from 2018-2020. To find out the variables of service quality and product quality that affect customer satisfaction.

The purpose of the survey is to determine customer satisfaction as early detection of the root of existing problems, which can hinder organizational performance and be used as a basis for improvement.

The population of respondents is 83 End-Customers and 56 Branches, with three representatives for each customer. With 83 \& 56 customers (417 respondents), the target respondents (using the Solvin formula with a margin of error of 10\%) are 81 respondents.

A customer satisfaction survey was distributed via SMS and Email to 417 respondents. The Customer Satisfaction Index calculation is done by dividing the weighted total by the nominal scale used then multiplying it by 100 percent.

The CSI formula is as follows:

Table 1 CSI Formula

\begin{tabular}{|c|c|l|l|}
\hline $\begin{array}{c}\text { Perception } \\
\text { Value }\end{array}$ & Interval & \multicolumn{1}{|c|}{ Score Interval } & Unit Performance \\
\hline 1 & $1,00-2,59$ & $25,00 \%-64,99 \%$ & $=$ Strongly Disagree \\
\hline 2 & $2,60-3,06$ & $65,00 \%-76,60 \%$ & $=$ Disagree \\
\hline 3 & $3,06-3,53$ & $76,61 \%-88,30 \%$ & $=$ Agree \\
\hline 4 & $3,53-4,00$ & $88,31 \%-100,00 \%$ & $=$ Strongly Agree \\
\hline
\end{tabular}

Result of Customer Satisfaction Survey Year 2020:

Table 2 Result of Customer Satisfaction Survey Year 2020

\begin{tabular}{|c|l|l|c|}
\hline No & Variable & \multicolumn{1}{|c|}{ Question } & CSI \\
\hline 1 & Empathy & $\begin{array}{l}\text { The company can understand my problems/complaints } \\
\text { and can provide solutions to the problems }\end{array}$ & $\mathbf{8 0 , 2 9 \%}$ \\
\hline 2 & Tangible & $\begin{array}{l}\text { The company provides components with the best } \\
\text { product quality assurance }\end{array}$ & $\mathbf{7 7 , 9 1 \%}$ \\
\hline 3 & Reliability & $\begin{array}{l}\text { Remanufacturing services provided by UTR comply with } \\
\text { remanufacturing work standards }\end{array}$ & $\mathbf{7 9 , 1 0 \%}$ \\
\hline 5 & $\begin{array}{l}\text { Perceived } \\
\text { Quality }\end{array}$ & $\begin{array}{l}\text { The company can be trusted because it has the expertise } \\
\text { and competence to handle the component problems } \\
\text { that I have }\end{array}$ & $\mathbf{7 9 , 1 0 \%}$ \\
\hline 6 & Aesthetics & $\begin{array}{l}\text { I am satisfied with the packaging I received as long as I } \\
\text { used the repair services from you }\end{array}$ & $\mathbf{8 0 , 9 8 \%}$ \\
\hline 7 & Responsiveness & $\begin{array}{l}\text { The company is fast / responsive in providing my } \\
\text { component needs }\end{array}$ & $\mathbf{7 8 , 3 1 \%}$ \\
\hline 10 & Durability & $\begin{array}{l}\text { The life time given is according to my wants and needs } \\
\text { equipment requirements }\end{array}$ & $\mathbf{7 2 , 3 5 \%}$ \\
\hline 9 & Serviceability & $\begin{array}{l}\text { I am satisfied with the service provided compared to } \\
\text { other remanufacturing companies }\end{array}$ & $\mathbf{7 6 , 3 2 \%}$ \\
\hline able to meet the needs of my equipment & $\mathbf{7 6 , 3 2 \%}$ \\
\hline
\end{tabular}




\begin{tabular}{|c|l|l|c|}
\hline 11 & Assurance & $\begin{array}{l}\text { The company provides services and / or products } \\
\text { according to the promised time }\end{array}$ & $\mathbf{7 4 , 3 3 \%}$ \\
\hline 12 & Conformance & $\begin{array}{l}\text { The components provided have the performance } \\
\text { approaching new components }\end{array}$ & $\mathbf{7 0 , 3 7 \%}$ \\
\hline 13 & Reliability & $\begin{array}{l}\text { The warranty given at this time (3000 hours / } 6 \text { months) } \\
\text { is according to my wishes }\end{array}$ & $\mathbf{6 5 , 9 1 \%}$ \\
\hline \multicolumn{2}{|l}{} & $\mathbf{7 6 , 2 4 \%}$ \\
\hline
\end{tabular}

\section{RESULT AND DISCUSSION}

\subsection{Quality Function Deployment}

Quality function deployment (QFD) is a method to transform user demands into design quality [6-7], as shown in Figure 7, to deploy the functions forming quality, and to deploy strategies for achieving the design quality into subsystems and parts, and ultimately to specific elements of the manufacturing process [8].

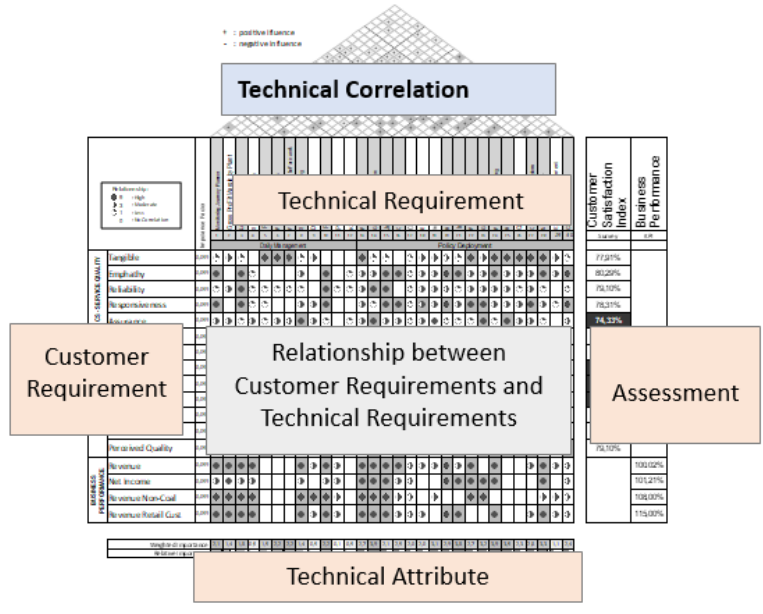

Figure 7 Quality function deployment

The relationship between TQM implementation and its impact on customer satisfaction and business performance is seen using the QFD method with the following provisions:

a. Customer Survey and Business Performance was placed as a target on the Customer requirements side.

b. Two aspects of TQM: Daily Management and Policy Management, are seen as Technical Requirements.

c. The results of the CS Index and achievement of business performance are seen as an assessment/achievement.

\subsection{Business Performance Result}

A. Defines the Scope of the Business

Performance
The implementation of TQM has an impact on company business performance, especially company performance until the end of 2020, as follows:

1. All revenue: 820 billion IDR or $100.02 \%$ of the target.

2. Revenue non-coal: 453.48 billion IDR or $125.27 \%$ growth from last year.

3. Revenue retail customer: 132.82 billion IDR or $105.18 \%$ growth from last year.

4. Net income: 13.85 billion IDR or $115.50 \%$ of the target.

\section{B. Correlation between Business Performance} and Daily Management - Policy Management Activities

First, analyse each daily management initiative or policy management for each business performance by providing relationship values: High (9), Moderate (3), Less (1) dan No Correlation (0).

Check out the examples below:

Table 3 Policy Management - Intensify Top ULTRA through product competitiveness to increase profitability (Example)

\begin{tabular}{|l|l|l|l|l|}
\hline $\begin{array}{l}\text { Control } \\
\text { Point SI }\end{array}$ & Target & $\begin{array}{l}\text { Activity } \\
\text { Management (AM) }\end{array}$ & $\begin{array}{l}\text { Check } \\
\text { Point } \\
\text { AM }\end{array}$ & $\begin{array}{l}\text { Relations } \\
\text { hip } \\
\text { Value }\end{array}$ \\
\hline $\begin{array}{l}\text { Top } \\
\text { ULTRA } \\
\text { Compone } \\
\text { nt Qty }\end{array}$ & 21 Qty & $\begin{array}{l}\text { Define } \\
\text { criteria/definition of } \\
\text { Top ULTRA }\end{array}$ & State & Mod.(3) \\
\hline & & $\begin{array}{l}\text { Calculate capacity } \\
\text { and Production Cost } \\
\text { in Production Plant's } \\
\text { Priority }\end{array}$ & Plant & Mod.(3) \\
\hline & $\begin{array}{l}\text { Evaluate Contri- } \\
\text { bution Margin (CM) } \\
\text { \& Gross Profit (GP) }\end{array}$ & Eval. & Doc. \\
\hline & $\begin{array}{l}\text { Set development } \\
\text { cost alternative to } \\
\text { increase CM \& GP }\end{array}$ & Doc. & State \\
\hline
\end{tabular}

\section{Business Performance and TQM Implementation}



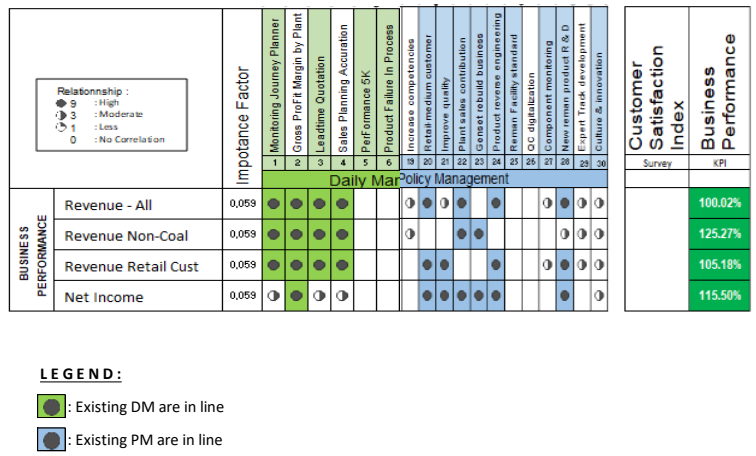

Figure 8 Business performance vs TQM implementation

Analysis:

1. All revenue performance is supported by 6 daily management activities and 8 policy management activities.

2. Revenue non-coal performance is supported by 7 daily management activities and 5 policy management activities.

3. Revenue retail customer performance is supported by 6 daily management activities and 7 policy management activities.

4. Net income performance is supported by 2 daily management activities and 9 policy management activities.

5. In carrying out each phase of strategic management, several tools are needed so that each phase can produce output as expected. What is expected is not only good output but also correct in the process.

The implementation of TQM has an impact on company business performance, especially company performance until the end of 2020, as follows:

1. All revenue: 820 billion IDR or $100.02 \%$ of the target.

2. Revenue non-coal: 453.48 billion IDR or $125.27 \%$ growth from last year

3. Revenue retail customer: 132.82 billion IDR or $105.18 \%$ growth from last year.

4. Net income: 13.85 billion IDR or $115.50 \%$ of the target.

\subsection{Customer Satisfaction Survey Result}

\section{A. Customer Satisfaction Survey and TQM Implementation}

In this research, we see the relationship between TQM Implementation through Daily Management and
Policy Management and its impact on the Customer Satisfaction survey with the following results:

1. There are several aspects of the CS Survey results that need to be improved: Assurance, Reliability, Conformance and Durability.

2. The four aspects that need to be improved, there is no significant relationship related to Daily Management: Assurance (1), Reliability (0), Conformance (0) and Durability (2).

3. The four aspects that need to be improved, there are already several Relationships related to Policy Deployment: Assurance (3), Reliability (4), Conformance (2) and Durability (9), but they must be analyzed more in their effectiveness.

\section{B. Modify the TQM Activity to Align with Customer Satisfaction}

Based on the results of the CS Index in the current year, there are unsatisfactory results on the attributes: Assurance (74.33\%), Reliability (65.91\%), Conformance $(70.37 \%)$ and Durability $(72.35 \%)$. This is in line with the lack of alignment between Daily Management activities against the four attributes or several Policy Management, which must be re-evaluated to be more effective.

Daily Management modifications are carried out as follows:

1. Continuing to use the control board of "Product Failure in Process".

2. Adding the control board of the "Product Failure in Field" control board.

3. Adding the control board of "Daily Inspection".

4. Adding the control board of "Claim Status" to control customer claim status.

Policy Management modifications are carried out as follows:

Existing Policy Management "Component life time" improvement project is shown in Figure 9 that aims to increase component life to be more focused on engine and cylinder products where both components have a significant impact on customer satisfaction and quality. 


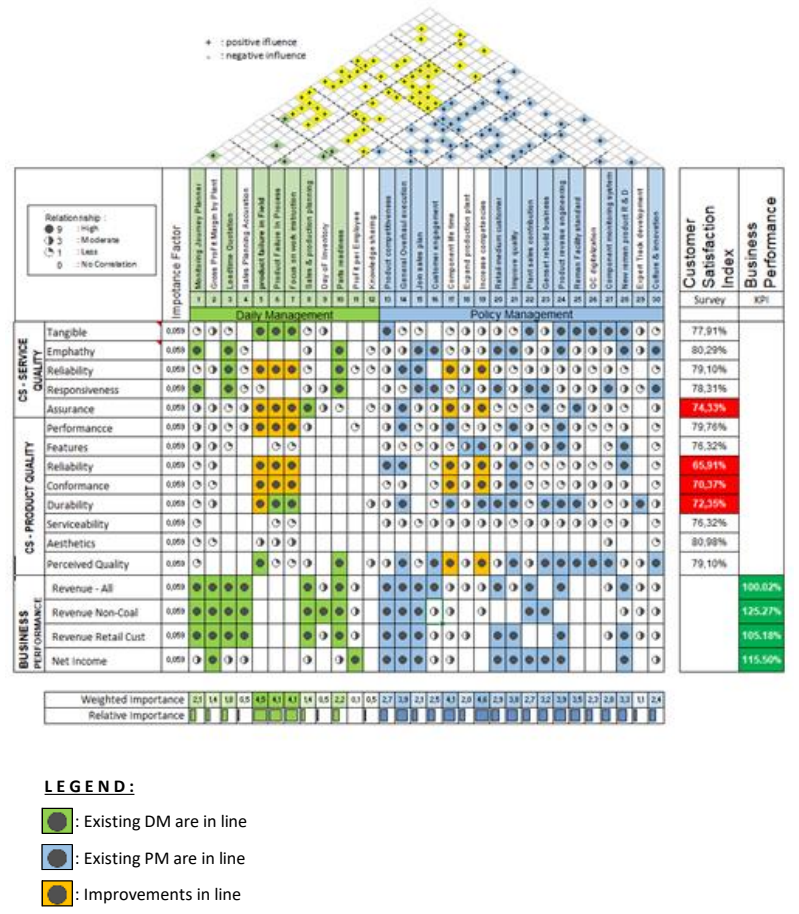

Figure 9 Quality function deployment - after improvement

\section{CONCLUSION}

a. The implementation of TQM has a significant impact on company business performance (as of Dec'2020): revenue (all): 820 bio-IDR (100.02\% of the target), and net income: 13.85 bio-IDR (115.50\% of the target).

b. The CS survey results for the category of service quality showed satisfactory results in line with TQM daily management and policy management activities as seen in the correlation diagram of the QFD method.

c. The CS survey results for the category of product quality showed unsatisfactory results so it is necessary to improve the activity of TQM by using the QFD correlation diagram.

d. Internal diagnosis by management as a feedback system with a good conformity value above $80 \%$, indicating the implementation of TQM can be sustainable.

\section{RECOMMENDATION}

In every company annual plan, it is crucial to consider customer satisfaction for next year's activity plans in line with Daily Management and Policy Management activities.

\section{AUTHORS’ CONTRIBUTIONS}

Bayu Cahyono made contributions as first authors. Data was collected and analysed by Bayu Cahyono and Sumarsono. All authors (Gembong Baskoro, Dena Hendriana, and Henry Nasution) made contributions to the design of the study and the writing of the manuscript.

\section{ACKNOWLEDGMENTS}

I Want to thank Dr .Eng. Sumarsono, S.T., M.T. and Dena Hendriana, B.Sc., S.M., Sc. D and all Lecturers guided me while studying at Swiss German University. And also to Mr Edhie Sarwono, who allowed me to take a master's degree.

\section{REFERENCES}

[1] I.N. Eugenia, Quality Improvement in a Global Competitive Marketplace-Success Story from Nigeria International Journal of Business and Management, 5(1), 2010, pp.211-218.

[2] K. Baird, K.J. Hu, R. Reeve, The Relationships Between Organizational Culture, Total Quality Management Practices and Operational Performance, Int. J. Oper. Prod. Manag. 31 (7), 2011, pp. 789-814.

[3] A.P. Anil and K.P. Satish, Investigating the Relationship Between TQM Practices and Firm's Performance: A Conceptual Framework for Indian Organizations, Procedia Technology 24 (2016) 554 -561 .

[4] Astra International, Astra Management System to Continually Strive for Excellence, Jakarta, 2014.

[5] S. Jakpar, A.G.S. Na, A. Johari, K. Myint, Examining the Product Quality Attributes that Influences Customer Satisfaction Most when the Price was Discounted: A Case Study in Kuching Sarawak, International Journal of Business and Social Science. Vol. 3(23), 2012, pp. 221-236.

[6] W. Rizlan, H.H. Purba, Sudiyono, Performance Maintenance Analysis Using QFD Method: A Case Study in Fabrication Company in Indonesia, 
Computer, Mathematics and Engineering Applications, Vol. 9(1), June 2018, pp.25-35.

[7] R. Wolniak, The use of QFD Method Advantages and Limitation, Production Engineering Archieves, Vol.18, 2018, pp.14-17. doi: 10.30657/pea.2018.18.02.

[8] R. Wolniak and A. Sedek, Using QFD Method for the Ecological Designing of Products and Services, Qual Quant, Vol. 43, 2009, pp.695-701. https://doi.org/10.1007/s11135-007-9160-9. 